\title{
COVER CROPPING AND INTERSEEDING MANAGEMENT PRACTICES TO IMPROVE RUNOFF QUALITY FROM DAIRY FARMS IN CENTRAL PENNSYLVANIA
}

\author{
Ryan G. Barnes ${ }^{1}$, C. Alan Rotz², Heather E. Preisendanz,"*, Jack E. Watson ${ }^{3}$, \\ Herschel A. Elliott ${ }^{1}$, Tamie L. Veith ${ }^{2}$, Clinton Williams ${ }^{4}$, Kathryn J. Brasier ${ }^{5}$ \\ ${ }^{1}$ Department of Agricultural and Biological Engineering, The Pennsylvania State University, University Park, Pennsylvania, USA. \\ ${ }^{2}$ USDA-ARS Pasture Systems and Watershed Management Research Unit, University Park, Pennsylvania, USA. \\ ${ }^{3}$ Department of Ecosystem Science and Management, The Pennsylvania State University, University Park, Pennsylvania, USA. \\ ${ }^{4}$ USDA-ARS Water Management and Conservation Research Unit, Maricopa, Arizona, USA. \\ ${ }^{5}$ Department of Agricultural Economics, Sociology, and Education, The Pennsylvania State University, University Park, Pennsylvania, USA. \\ *Correspondence: heg12@psu.edu.
}

\section{Highlights}

- Three crop scenarios for eight dairy farm types were simulated using the Integrated Farm System Model.

- Cover cropping and interseeding each significantly reduced runoff losses, compared to the baseline, for most farm types.

- Interseeding averaged greater reductions in N, P, and sediment losses than cover cropping.

- Increases in average annual production costs were $<2 \%$ of the baseline for most farm types.

\begin{abstract}
Intensive agricultural activities are known to increase nutrient and sediment losses, leading to degraded water quality in receiving water bodies. In the Chesapeake Bay watershed, animal operations must reduce farm-level nutrient and sediment losses to meet federally mandated load reduction goals. This work investigated the potential water quality benefits and economic impacts of adopting post-harvest cover cropping or interseeded cover cropping on eight dairy farms representative of common operations in central Pennsylvania. The farms, simulated with the Integrated Farm System Model (IFSM), represented confined, organic, grazing, and Amish farming practices for dairy herds ranging in size from 35 to 150 lactating Holstein cows. Simulations were run for 25 years using observed weather data for Mifflin County, Pennsylvania, and for the dominant agricultural soil series in the county: Hagerstown silt loam. Model output included water balance results, nutrient and sediment loads, and farm-scale economics at an annual scale. Overall, simulation results showed that post-harvest cover cropping reduced $N, P$, and sediment by 18\%, 17\%, and 42\%, respectively, while interseeding reduced loads by 49\%, 41\%, and 46\%, respectively. Economic impacts of cover cropping and interseeding varied among farm types, but nearly all scenarios resulted in a net loss in profit compared to the baseline. However, annual economic losses were relatively minor: less than $\$ 28 \mathrm{ha}^{-1}$ for cover cropping and $\$ 63 \mathrm{ha}^{-1}$ for interseeding. Results suggest that the benefits of interseeding cover crops are greater for farms with larger portions of land in row crops with less perennial grassland. Interseeding necessitates purchasing additional equipment or custom hiring the seeding operation. These results have implications for cost-share incentive structures aimed at promoting adoption of cover crops and interseeding, especially for confined farms, which may otherwise experience financial losses if these practices are adopted.
\end{abstract}

Keywords. Best management practice, Conservation, Economic evaluation, Erosion, IFSM, Integrated Farm System Model, Nutrient transport, Water quality.

\footnotetext{
(c) $(1) \Theta$ The authors have paid for open access for this article. This work is licensed under a Creative Commons AttributionNonCommercial-NoDerivatives 4.0 International License https://creative commons.org/licenses/by-nc-nd/4.0/

Submitted for review on 27 September 2020 as manuscript number NRES 14329; approved for publication as a Research Article by the Natural Resources \& Environmental Systems Community of ASABE on 20 April 2021.

Mention of company or trade names is for description only and does not imply endorsement by the USDA. The USDA is an equal opportunity provider and employer.
}

A nthropogenic activities have caused widespread degradation of freshwater and saltwater ecosystems worldwide, with increased fluxes of growth-limiting nutrients and excess sediment from agricultural activities often the primary causes of coastal eutrophication. As the largest estuary in the U.S., the Chesapeake Bay has suffered from degraded water quality and hypoxia for decades and is one of more than 400 coastal water bodies experiencing eutrophication worldwide (Selman et al., 2008). Increased nutrient and sediment loadings to the bay have caused significant economic losses, such as decline in the blue crab population, which is a staple food item for the region (Pelton and Goldsborough, 2008). 
Pennsylvania ranks 14th nationwide in the production of livestock, poultry, and animal products and 6th for milk production (USDA-NASS, 2017). Livestock manure and poultry litter are large contributors of growth-limiting nutrients, contributing $19 \%$ of total $\mathrm{N}$ and $26 \%$ of total P delivered to the Chesapeake Bay (USEPA, 2010). The Susquehanna River, which drains approximately half the land area of Pennsylvania, is the largest contributor of freshwater to the Chesapeake Bay (Schubel and Pritchard, 1986) and comprises $32.8 \%$ of the Chesapeake Bay watershed total maximum daily load (TMDL). The Susquehanna River basin, particularly the lower basin, experiences high erosion rates (Reuter et al., 2005), creating many issues for aquatic ecosystems including high turbidity and burial of fish spawning habitat in layers of silt (Syvitski et al., 2005). Erosion is recognized as a major factor in the degradation of landscapes. Land management and land cover typically render agricultural soils more vulnerable to erosion than forested or grassland soils (Yu et al., 2016).

As a substantial contributor to reduced water quality in the Chesapeake Bay, the Susquehanna River basin has been identified by federal policymakers as lacking in both funding and implementation of practices to adequately reduce $\mathrm{N}$, $\mathrm{P}$, and sediment from agriculture, stormwater, and urban development (Chesapeake Bay Foundation, 2020). Specific to agriculture, significant efforts have been made to increase adoption of cover crops, conservation tillage, and forested and riparian buffers to meet TMDL goals. However, uncertainties regarding the effectiveness and associated costs have led to lower adoption than anticipated (Liu et al., 2017).

Cover crops can play an important role in modern agriculture, often increasing row crop productivity by improving the soil's physical, biological, and chemical properties. A cover crop can be defined as a close-growing species that provides soil improvements and protection between periods of normal crop production (Fageria et al., 2005). Winter cereal cover crops are commonly planted in the Chesapeake Bay watershed in rotation with row crops, aiming to reduce nutrient and sediment losses from agricultural systems. The prevalence of cover cropping is generally increasing, with adoption of cover cropping after corn in the south-central parts of Pennsylvania having increased from $40 \%$ to $66 \%$ from 2009 to 2013 (Hively et al., 2015).

Corn silage, a primary forage for dairy cows, entails harvesting the entire corn plant, which limits the quantity of organic matter and nutrients recycled back into the soil and increases the nutrient needs for the following year's crop (Moore et al., 2014). This, in addition to the reduction of ground cover, makes corn silage production one of the most detrimental agricultural practices for soil quality (Moore et al., 2014). In particular, the lack of ground cover after harvest leaves the soil surface more prone to splash erosion from the impact of rainfall, which breaks down soil aggregates (Fernández-Raga et al., 2017). Planting a cover crop on what would otherwise be fallow soil enhances soil aggregate stability, increases soil hydraulic conductivity, and reduces surface runoff (Yu et al., 2016). Thus, cover cropping represents a critical best management practice (BMP) with potential for abating degraded water and soil quality.
Nationwide, cover crop adoption is increasing. According to the 2017 USDA Census of Agriculture, cover crop acreage had increased by 50\% over 2012 levels. Yet adoption remains low in the upper Mid-Atlantic region, largely due to the short growing season available following corn harvest (Curran et al., 2018). Satellite imagery data show that in $2013,25 \%$ to $48 \%$ of corn fields in southeastern Pennsylvania did not have adequate vegetative cover over the winter to protect the soil surface, indicating a further need for cover crop adoption (Hively et al., 2015).

In practice, cover crop planting involves different approaches. One approach is simply to plant into the fallow soil after fall harvest, although weather conditions often limit successful seed germination. An alternative approach is interseeding, in which an understory species is planted into the growing row crop before harvest (Roth et al., 2015, 2017). Recent research done across the Mid-Atlantic region (New York, Pennsylvania, and Maryland) tested the feasibility of interseeding various species (annual rye, legume species, and a rye-grass legume mixture) with corn grown for grain and silage (Curran et al., 2018). All crop species were able to successfully establish and produce biomass during the fall and spring seasons. Corn yields were not affected when interseeding was done at or after the corn had reached the V4 stage, when a fourth leaf collar band is visible. A metaanalysis by Thapa et al. (2018) found that, although cover cropping studies thus far have focused on grass species, specifically cereal rye, more so than on legume cover crops, nonlegumes have demonstrated greater water quality benefits than legume or legume mix crops.

The goal of this research project was to better understand the potential physical and economic impacts of traditional post-harvest cover cropping and interseeded cover cropping in the humid temperate climate of the Mid-Atlantic U.S., specifically: (1) how the nutrient and sediment reduction benefits of interseeding compare to adoption of post-harvest cover crops on dairy farms, (2) how nutrient and sediment load reductions vary based on farm type, and (3) how the economic implications of adopting post-harvest cover cropping (post-harvest $\mathrm{CC}$ ) or interseeded cover cropping (interseeded CC) compare to the baseline scenario for each farm type.

Understanding how post-harvest CC and interseeding affect water balance and production processes at the field and farm scales can help improve the application and effectiveness of these BMPs. For example, this information can aid with efforts in developing relationships with landowners who are considering investing capital into BMPs toward meeting Pennsylvania's TMDL goals, but who also have questions about the cost and effectiveness of BMPs in their locale. However, post-harvest $\mathrm{CC}$ or interseeded $\mathrm{CC}$ as BMPs are not limited to Pennsylvania nor the Chesapeake Bay watershed but are applicable worldwide to row crop systems in similar soils and climates.

\section{Materials AND Methods \\ STUDY SITE}

The study site, Mifflin County, was selected for multiple reasons, including its location in the Susquehanna River 
Table 1. Summary of Mifflin County land use (USDA-NASS, 2017).

\begin{tabular}{lcc}
\hline Land Use & $\begin{array}{c}\text { Area } \\
\text { (ha) }\end{array}$ & $\begin{array}{c}\text { Percentage of Total } \\
\text { County Area (\%) }\end{array}$ \\
\hline Agriculture & 1060 & 24.4 \\
Forested & 2928 & 67.4 \\
Developed & 314 & 7.2 \\
Other & 45 & 1.0 \\
\hline & Area & Percentage of Total \\
Agriculture Land Breakdown & (ha) & Agriculture Land (\%) \\
\hline Row crops & 555 & 52.4 \\
Hay/alfalfa/clover & 323 & 30.5 \\
Pasture & 151 & 14.2 \\
Cover crops & 1.3 & 0.1 \\
Small grains & 5.7 & 0.5 \\
Other & 24 & 2.3 \\
\hline
\end{tabular}

basin and the Chesapeake Bay watershed, and its priority ranking as in the top third of counties for nitrogen and phosphorus load reduction under the Pennsylvania Phase III Watershed Implementation Plan (PADEP, 2019). Additionally, limited stakeholder engagement in this county around the topic of cover cropping had occurred prior to the commencement of this project, and a clear need was identified by the project team for providing technical support to local dairy farms. The county's 711 working farms cover roughly $25 \%$ of the county's land area (table 1) and produce nearly $\$ 140$ million annually in agricultural products (USDANASS, 2017). The county ranks 12 th in the state for milk production, with milk sales contributing $32 \%$ of the county's annual agricultural sales (USDA-NASS, 2017).

The county is the headwaters for Kishacoquillas Creek, which is a tributary of the Susquehanna River in the Chesapeake Bay watershed. Kishacoquillas Creek (USGS 01565000) is impaired for sediment and is currently developing a Phase III Watershed Implementation Plan to comply with the Chesapeake Bay TMDL (PADEP, 2017, 2019).

\section{MODEL OVERVIEW}

The Integrated Farm System Model (IFSM) simulates the major farm components on a process level and represents major interactions between the biological, chemical, and physical processes occurring on a farm (Rotz et al., 2018). Crop production, hydrology, and nutrient cycles are calculated at a daily time scale, with outputs generated as mean annual values. Daily observed weather data for Lewistown, Pennsylvania (Mifflin County), general farm management practices, and county-level soils data from the Natural Resources Conservation Service (NRCS) Web Soil Survey (USDA-NRCS, 2020) were specified as inputs. The predominant soil series in Mifflin County is Hagerstown (fine, mixed, semiactive, mesic Typic Hapludalfs), consisting of well-drained, deep, silt loams and silt clay loams typically found on slopes ranging from $3 \%$ to $15 \%$ and comprising $42 \%$ of the agricultural land (USDA-NRCS, 2020).

Simulations were run for 25 years, from 1990 to 2015, so that the effects of varying levels of precipitation (e.g., wet, dry, and average years) were well-represented in the variability of model predictions. The model enables researchers, landowners, and farm managers to explore the effects of different farm management scenarios on resource use, production efficiency, environmental impact, and production costs.

\section{FARM TYPES AND CROPPING SCENARIOS}

IFSM (version 4.5) simulations were run using a suite of dairy operations representative of dairy farms in Mifflin County and elsewhere in Pennsylvania. The eight dairy operations simulated were: confined 150-cow, confined 50-cow, semi-confined 100-cow, semi-confined 50-cow, organic 50-cow, grazing 50-cow, Amish 70-cow, and Amish 35-cow (table 2). Confined operations were those dairies where all cattle were maintained in a barn or open lot throughout the year. In semi-confined production, cattle were maintained in barns or lots but some grazing, often for heifers and perhaps non-lactating cows, was used in the spring and summer months. For management-intensive grazing systems, cattle received at least $40 \%$ of their annual forage requirement from grazed pasture. Organic farms also relied heavily on grazing while following certified organic practices. The Amish are an ethnic group that farm with limited use of powered equipment, relying on horses or other working animals for conducting farm operations. Amish farms are small with a high animal density per unit of available land (Holly et al., 2019; McLean, 2011). The two Amish farms were similar except that the larger farm had a lower animal density with greater use of perennial grassland (table 2), and most field operations were custom hired rather than farmed using horses. The size of each operation reflects the number of mature cows and includes both lactating and dry cows. Production of replacement heifers was included on each farm, with 0.2 to 0.4 heifers produced per cow depending on farm type and cow replacement rate.

The farm-level environmental and economic impacts of post-harvest $\mathrm{CC}$ and interseeded $\mathrm{CC}$ were evaluated using three IFSM simulation scenarios on each of the eight farm types:

Scenario 1: Corn silage (Zea mays with a maturity index of 115 to 120 days) fields were left untouched after harvest and provided little to no ground cover (tillage and manure treatments varied by farm type).

Scenario 2: A cereal rye (Secale cereal L.) cover crop was planted into all corn silage fields, immediately after the September corn-silage harvest, and was killed in the spring just prior to corn planting and left to decompose (fig. 1). Cereal rye is inexpensive to plant with a low seed cost (Schnitkey et al., 2018). Cereal rye is also hardy in central Pennsylvania's cool climate, with easy establishment and quick regrowth in the spring, making it a potentially cost-effective choice for conservation by cover crop (Bowman et al., 2007; Clark, 2015).

Scenario 3: An annual rye grass was interseeded into all corn grain and silage fields in early June (fig. 1) when the corn was expected to have reached the vegetative V5 to V7 stages (Rotz et al., 2018). The grass was killed in the spring and left to decompose similarly to the rye cover crop. Through decomposition, nutrients are slowly released during the growing season, supplementing the requirement of the succeeding crop.

Cover crops were established using the practices defined for other crops on the farm. For most farms, this included a tillage operation. On the two farms that used no-till crop establishment (confined 50-cow and semi-confined 100-cow), no-till seeding was used. The cover and interseeded crops 
Table 2. Characteristics of eight dairy production systems simulated in central Pennsylvania.

\begin{tabular}{|c|c|c|c|c|c|c|c|c|}
\hline & $\begin{array}{l}\text { Confined } \\
150-\text { Cow }\end{array}$ & $\begin{array}{c}\text { Confined } \\
50-\text { Cow }\end{array}$ & $\begin{array}{c}\text { Semi- } \\
\text { Confined } \\
\text { 100-Cow } \\
\end{array}$ & $\begin{array}{c}\text { Semi- } \\
\text { Confined } \\
\text { 50-Cow }\end{array}$ & $\begin{array}{l}\text { Organic } \\
50-\text { Cow }\end{array}$ & $\begin{array}{l}\text { Grazing } \\
50-\text { Cow }\end{array}$ & $\begin{array}{l}\text { Amish } \\
\text { 70-Cow }\end{array}$ & $\begin{array}{l}\text { Amish } \\
\text { 35-Cow }\end{array}$ \\
\hline Number of cows & 150 & 50 & 100 & 50 & 50 & 50 & 70 & 35 \\
\hline Number of older heifers & 58 & 19 & 37 & 19 & 16 & 16 & 26 & 13 \\
\hline Number of young heifers & 60 & 19 & 38 & 19 & 17 & 16 & 26 & 13 \\
\hline Replacement rate (\%) & 38 & 36 & 28 & 35 & 20 & 30 & 35 & 35 \\
\hline Breed & Holstein & Holstein & Holstein & Holstein & Mixed & Holstein & Holstein & Holstein \\
\hline Milk production $\left(\mathrm{L} \mathrm{cow}^{-1}\right.$ year $\left.^{-1}\right)$ & 9450 & 8770 & 9690 & 8770 & 6500 & 7880 & 8850 & 8860 \\
\hline Calving strategy & Year round & Year round & Year round & Year round & Year round & Spring cycle & Year round & Year round \\
\hline Cow housing & Free stall & Tie stall & Free stall & Tie stall & Tie stall & Tie stall & tie stall & Tie stall \\
\hline Heifer housing & Slatted floor & Bedded pack & Free stall & Bedded pack & Open lot & Open lot & Bedded pack & Bedded pack \\
\hline Cow manure handling & Slurry & Daily haul & Slurry & Daily haul & Daily haul & Daily haul & Slurry tank & Daily haul \\
\hline Heifer manure handling & Slurry & Solid & Slurry & Solid & Solid & None & Solid & Solid \\
\hline Bedding type & Straw & Straw & Straw & Straw & Saw dust & Straw & Saw dust & Saw dust \\
\hline Manure application & Incorporated & Broadcast & Broadcast & Broadcast & Broadcast & Broadcast & Broadcast & Broadcast \\
\hline Hay storage & Shed & Shed & Shed & Shed & Shed & Shed & Shed & Shed \\
\hline Silage storage & Bunker & Stave silo & Stave silo & Stave silo & Bale/bag & Bag & Bag/stave silo & Stave silo \\
\hline Grain storage & Bin & Bin & Bin & Bin & None & None & None & Bin \\
\hline Alfalfa area (ha) & 30 & 15 & 15 & 7 & 5 & 13 & 15 & 7 \\
\hline Grass area (ha) & 30 & 15 & 36 & 20 & 30 & 30 & 20 & 5 \\
\hline Corn area (ha) & 90 & 25 & 25 & 15 & 6 & 5 & 15 & 7.5 \\
\hline Cover crop area (ha) & 45 & 8.8 & 15 & 7 & 5 & 6 & 15 & 7.5 \\
\hline Interseed crop area (ha) & 90 & 25 & 25 & 15 & 6 & 5 & 15 & 7.5 \\
\hline Pasture area (ha) & 0 & 10 & 15 & 20 & 30 & 20 & 15 & 3 \\
\hline Stocking rate (cows ha ${ }^{-1}$ ) & 1.0 & 0.9 & 1.3 & 1.2 & 1.2 & 1.0 & 1.4 & 1.8 \\
\hline Alfalfa yield (t DM ha-1) & 8.2 & 10.5 & 12.2 & 9 & 8.1 & 10.4 & 9.2 & 8.6 \\
\hline Grass yield (t DM ha $\left.{ }^{-1}\right)$ & 5.1 & 6.2 & 5.9 & 5.9 & 5.6 & 4.7 & 5 & 6.2 \\
\hline Corn silage yield (t DM ha-1) & 15.8 & 15.8 & 16.6 & 14.2 & 14.8 & 18.5 & 13.5 & 14.1 \\
\hline Corn grain yield $\left(\mathrm{t} \mathrm{DM} \mathrm{ha}{ }^{-1}\right)$ & 7.2 & 7.6 & 7.8 & 6.8 & - & - & - & 7.6 \\
\hline Manure distribution (\%) & $\begin{array}{l}20 \text { grass, } \\
80 \text { corn }\end{array}$ & $\begin{array}{c}5 \text { alfalfa, } \\
25 \text { grass, } \\
70 \text { corn }\end{array}$ & $\begin{array}{c}5 \text { alfalfa, } \\
40 \text { grass, } \\
50 \text { corn }\end{array}$ & $\begin{array}{c}10 \text { alfalfa, } \\
45 \text { grass, } \\
45 \text { corn }\end{array}$ & $\begin{array}{l}50 \text { grass, } \\
50 \text { corn }\end{array}$ & $\begin{array}{c}10 \text { alfalfa, } \\
80 \text { grass, } \\
10 \text { corn }\end{array}$ & $\begin{array}{c}10 \text { alfalfa, } \\
40 \text { grass, } \\
50 \text { corn }\end{array}$ & $\begin{array}{c}10 \text { alfalfa, } \\
50 \text { grass, } \\
40 \text { corn }\end{array}$ \\
\hline Tillage method & Minimum & No-till & No-till & Full & Full & Full & Full & Full \\
\hline $\mathrm{N}$ fertilizer use $\left(\mathrm{kg} \mathrm{N} \mathrm{ha}^{-1}\right)$ & $\begin{array}{c}33 \text { grass, } \\
40 \text { corn }\end{array}$ & $\begin{array}{c}60 \text { grass, } \\
50 \text { corn }\end{array}$ & $\begin{array}{c}30 \text { grass, } \\
20 \text { corn }\end{array}$ & $\begin{array}{c}30 \text { grass, } \\
50 \text { corn }\end{array}$ & None & $\begin{array}{c}30 \text { grass, } \\
30 \text { corn }\end{array}$ & $\begin{array}{c}30 \text { grass, } \\
50 \text { corn }\end{array}$ & $\begin{array}{c}30 \text { grass, } \\
20 \text { corn }\end{array}$ \\
\hline Soils & $\begin{array}{c}\text { Hagerstown } \\
\text { silty clay } \\
\text { loam }\end{array}$ & $\begin{array}{l}\text { Opequon- } \\
\text { Hagerstown } \\
\text { complex }\end{array}$ & $\begin{array}{l}\text { Opequon- } \\
\text { Hagerstown } \\
\text { complex }\end{array}$ & $\begin{array}{c}\text { Hagerstown } \\
\text { silt loam }\end{array}$ & $\begin{array}{c}\text { Hagerstown } \\
\text { silt loam }\end{array}$ & $\begin{array}{c}\text { Opequon- } \\
\text { Hagerstown } \\
\text { complex }\end{array}$ & $\begin{array}{c}\text { Hagerstown } \\
\text { silt loam }\end{array}$ & $\begin{array}{c}\text { Opequon } \\
\text { silty clay } \\
\text { loam }\end{array}$ \\
\hline Available water (mm) & 160 & 160 & 160 & 120 & 120 & 160 & 120 & 100 \\
\hline Density $\left(\mathrm{g} \mathrm{cm}^{-3}\right)$ & 1.36 & 1.4 & 1.4 & 1.36 & 1.36 & 1.4 & 1.36 & 1.33 \\
\hline Loam content $(\%)$ & 53 & 44 & 44 & 52 & 52 & 44 & 52 & 48 \\
\hline Clay content (\%) & 31 & 41 & 41 & 33 & 33 & 41 & 33 & 38 \\
\hline Sand content $(\%)$ & 16 & 15 & 15 & 15 & 15 & 15 & 15 & 14 \\
\hline
\end{tabular}

\section{Post Harvest Cover Crop}

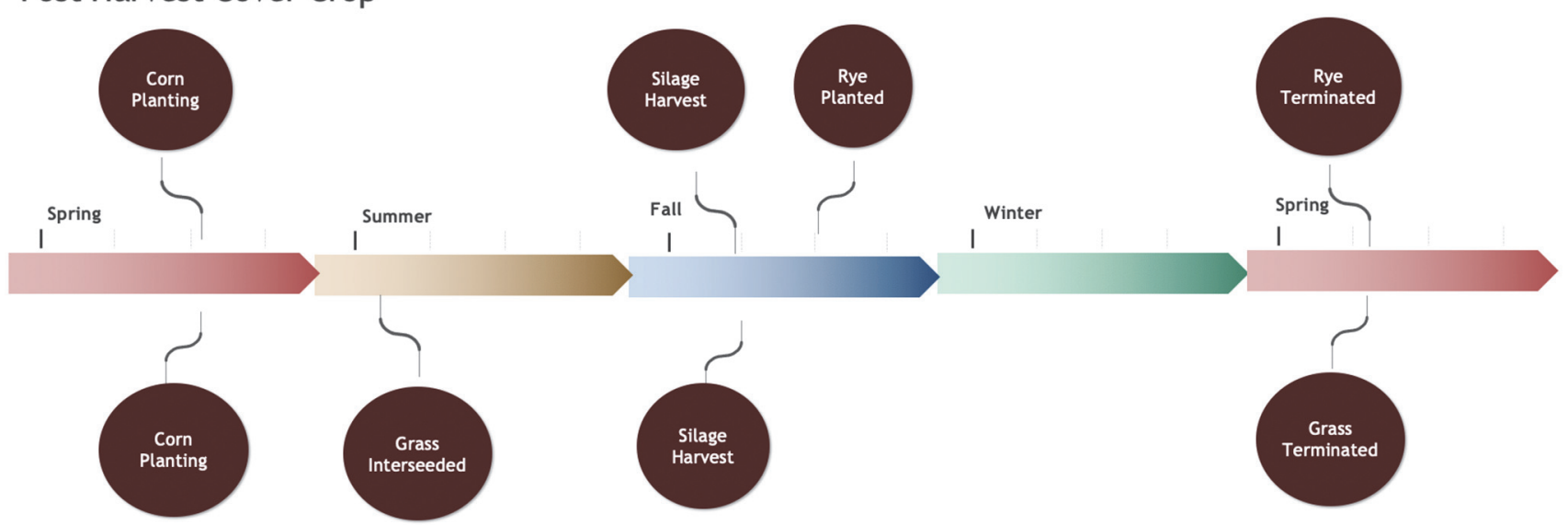

Interseeded Cover Crop

Figure 1. General timeline for post-harvest cover crops and interseeded cover crop operations in a corn field. 
were killed on most farms by tillage operations used to establish the succeeding crop. For the two farms that used notill crop establishment, a herbicide treatment was used prior to establishment of the succeeding crop. The establishment of post-harvest cover crops was simulated using the equipment, fuel, and labor available on the farm with an added seed cost of $\$ 21 \mathrm{ha}^{-1}$. For interseeding, a custom operation was assumed to be hired at a cost of $\$ 50 \mathrm{ha}^{-1}$ because this more expensive equipment was not readily available nor cost-effective to own by the producer.

Changes in soil cover due to the rye or interseeded grass were modeled by adjusting runoff curve numbers. Using the NRCS guide for the Hagerstown soil, which is categorized in hydrologic soil group B, corn land use was assigned a curve number of 81 (USDA-NRCS, 2004). In contrast, curve numbers for the rye cover crop and interseeded grass were set at 78.4 and 72.2, respectively. Within the model, a curve number is set for each crop, and the value is adjusted throughout the year as influenced by ground cover and soil moisture (Rotz et al., 2018). Therefore, when the corn crop transitions to the cover crop, the curve number adjusts to the value assigned by cover crop type for that portion of the year and the portion of the corn crop covered.

The rye was only double-cropped with corn silage because of the earlier harvest date associated with silage harvest compared to grain harvest. This earlier harvest date allowed the cover crop to achieve adequate growth entering the winter months (Hively et al. 2015). The difference in these areas for the farm types (table 2) altered the costs associated with interseeding and cover cropping for each farm.

\section{Hydrological and Biogeochemical Processes}

IFSM simulates hydrological responses to weather data and tracks nutrient cycling and loss of sediment via erosion as a function of farm management decisions. Hydrologic partitioning in IFSM is determined based on curve numbers (Jones and Kiniry, 1986). Sediment transport is simulated using the Modified Universal Soil Loss Equation (MUSLE) (Williams, 1995). The model represents the phosphorus (P) cycle using the Erosion-Productivity Impact Calculator (EPIC) and the Soil-Water Assessment Tool (SWAT) (Jones et al., 1984; Williams, 1995), with P movement and transport as functions of surface and subsurface soil pools containing both organic and inorganic P (Sedorovich et al., 2007). IFSM simulates multiple pathways of $\mathrm{N}$ loss from the landscape via volatilization, leaching, denitrification, and surface runoff (Rotz et al., 2018).

\section{Data ANalysis}

Hydrology, sediment, and nutrient outputs for scenario 2 (rye cover) and scenario 3 (grass interseeding) were compared statistically to scenario 1 (conventional, with no cover cropping) within each farm type. A two-sided t-test was conducted at a confidence level of 0.95 on the 25 annual totals generated for the baseline, cover crop, and interseeding scenarios for the given parameters. Comparisons were made between the three scenarios for all eight farms, providing insight into the extent of the benefits gained from the adoption of cover crops and interseeding for each farm type consider- ing the variability due to weather. These results were used to identify the benefits that can be gained from the adoption of cover crops and interseeding.

An economic analysis was conducted to assess the economic stress that cover cropping or interseeding placed on the producer. The average annual net returns, calculated by IFSM annually as the sum of all revenues minus the sum of all production costs and then averaged across the 25-year simulation (Rotz et al., 2018), for scenario 2 (cover crop) and scenario 3 (interseeding) were compared to scenario 1 (baseline conditions) to evaluate the economic impacts that adoption of cover cropping and interseeding had on farm profitability across the eight dairy farm operations.

\section{RESULTS AND DISCUSSION \\ WATER BALANCE}

Annual precipitation for Lewistown, Pennsylvania, averages $1,052 \mathrm{~mm}$, with $19 \%$ occurring during the winter and the remainder distributed evenly into the spring, summer, and autumn seasons (Arguez et al., 2010). Only $0.2 \%$ of cropland in Mifflin County receives irrigation on an annual basis (USDA-NASS, 2017), and thus irrigation was neglected in the water balance. Under scenario 1, hydrologic partitioning among the eight farm types varied minimally. Farms with more land in row-crop production (confined and Amish) experienced on average slightly more runoff and less drainage than farms with land in perennial grassland (semiconfined, grazing, and organic). The portion of the water balance that becomes surface runoff is important, as surface runoff drives nutrient and sediment loads. The IFSM simulations estimated that approximately $62 \%$ to $65 \%$ of outgoing water left as evapotranspiration (ET), $27 \%$ to $32 \%$ drained through the soil surface into the groundwater, and $4 \%$ to $7 \%$ became surface runoff. The results are in general agreement with expectations, as the average ET rate for central Pennsylvania is around $60 \%$ of the total precipitation (Sanford and Selnick, 2012), and 30\% to $40 \%$ of the annual precipitation in Mifflin County is estimated to recharge the groundwater (Reese and Risser, 2010).

The addition of post-harvest CC (scenario 2) reduced surface runoff and increased drainage as compared to the baseline for all eight farms (fig. 2). Interseeded CC (scenario 3) further reduced surface runoff and increased drainage for all eight farms. However, significant runoff reductions only occurred for three farms that used some degree of confinement (confined 150, confined 50, and semi-confined 50), and only for interseeding (fig. 2). This is due to the confined operations using a smaller percentage of grassland with a greater use of row-crops. Both confined operations showed significant runoff reductions $(\mathrm{p}<0.05)$ for interseeding when compared to both the baseline and cover crop scenarios (fig. 2) due to the higher animal concentrations and lesser use of grassland. In addition, the semi-confined 50-cow operation showed a significant runoff reduction for interseeding. ET did not change significantly across any scenario for any of the eight farms, and drainage showed no statistically significant changes relative to the baseline for either cover crop type (fig. 2). 

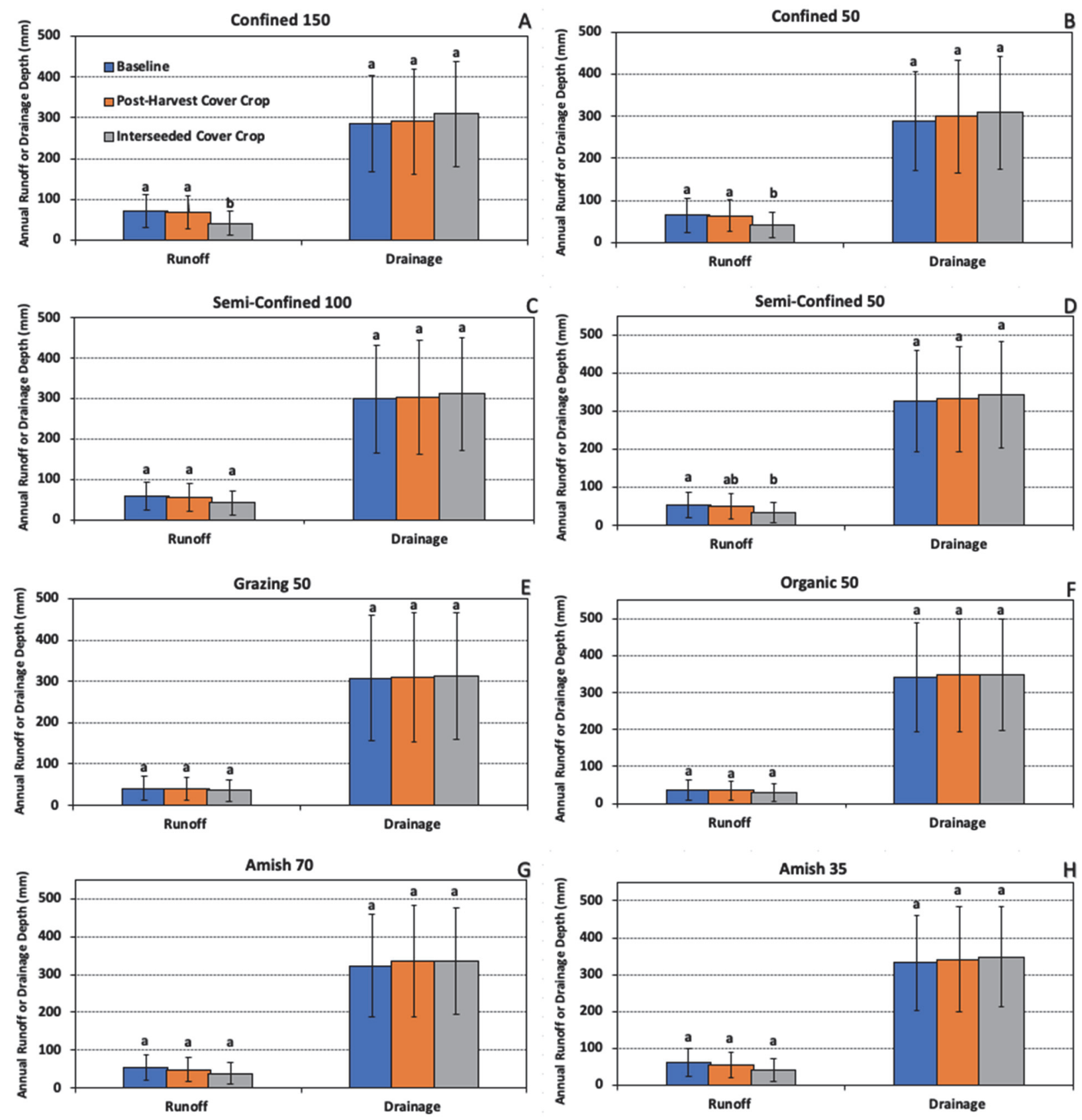

Figure 2. Average soil water balance (mm) simulated over 25 years for (a) confined 150-cow, (b) confined 50-cow, (c) semi-confined 100-cow, (d) semi-confined 50-cow, (e) grazing 50-cow, (f) organic 50-cow, (g) Amish 70-cow, and (h) Amish 35-cow dairy operations. Error bars represent standard deviations. Different lowercase letters indicate a significant difference at $\mathrm{p}<0.05$.

\section{EROSION}

It is important to note that all eight farms started out under what would be considered good management for erosion control. Through the use of perennial crops and conservation tillage, sediment losses are relatively low. Hagerstown silty clay loam, the predominant soil for agricultural land in Mifflin County, has a T value of $11,200 \mathrm{~kg} \mathrm{ha}^{-1}$, representing the maximum average annual erosion rate that can occur before crop productivity is significantly affected (USDA-NRCS, 2003). On all eight farms, simulated annual erosion was less than 2,000 $\mathrm{kg} \mathrm{ha}^{-1}$, well below the T value. The region's most erodible soil, Opequon, has a $\mathrm{T}$ value of approximately $2,150 \mathrm{~kg} \mathrm{ha}^{-1}$, which still exceeds the simulated erosion rates from the eight farms modeled.
Cover crops (scenario 2) reduced erosion for all eight farm types as compared to the baseline $(p<0.05)$ except for the semi-confined 100-cow, grazing 50-cow, and organic 50 -cow operations, where a greater portion of the farm was in perennial grassland (fig. 3). The semi-confined 100-cow operation used no-till practices and had very little erosion even under the baseline scenario. Both the grazing 50-cow and organic 50-cow operations also had more perennial grassland and less annual cropland than the confined or semi-confined operations as a percentage of the farm's total landmass. Because the majority of farmland on both the grazing and organic farms was in pasture, baseline erosion rates (approx. $270 \mathrm{~kg} \mathrm{ha}^{-1}$ ) were low. Post-harvest cover crops and interseeding practices were not found to be as 

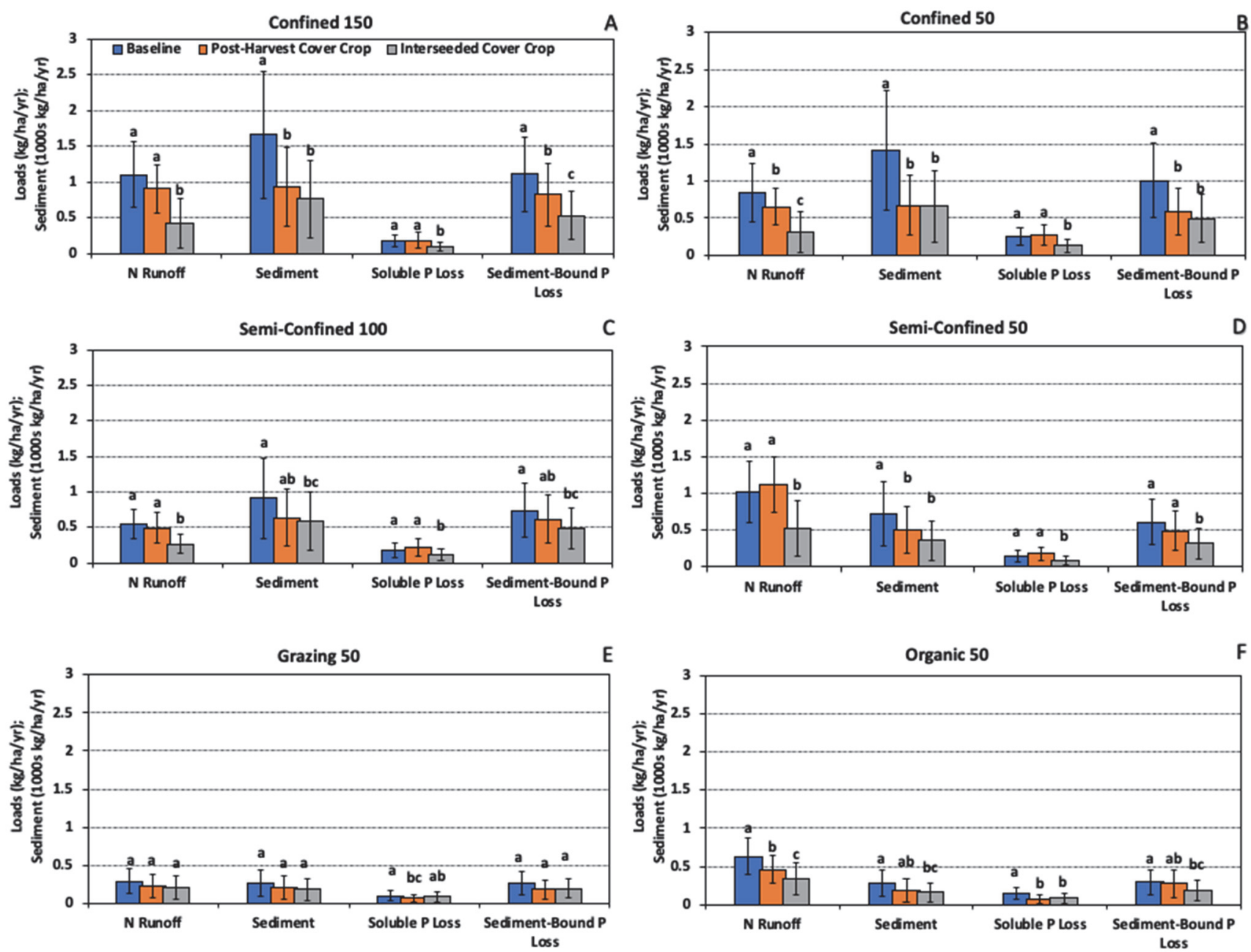

$\mathrm{E}$
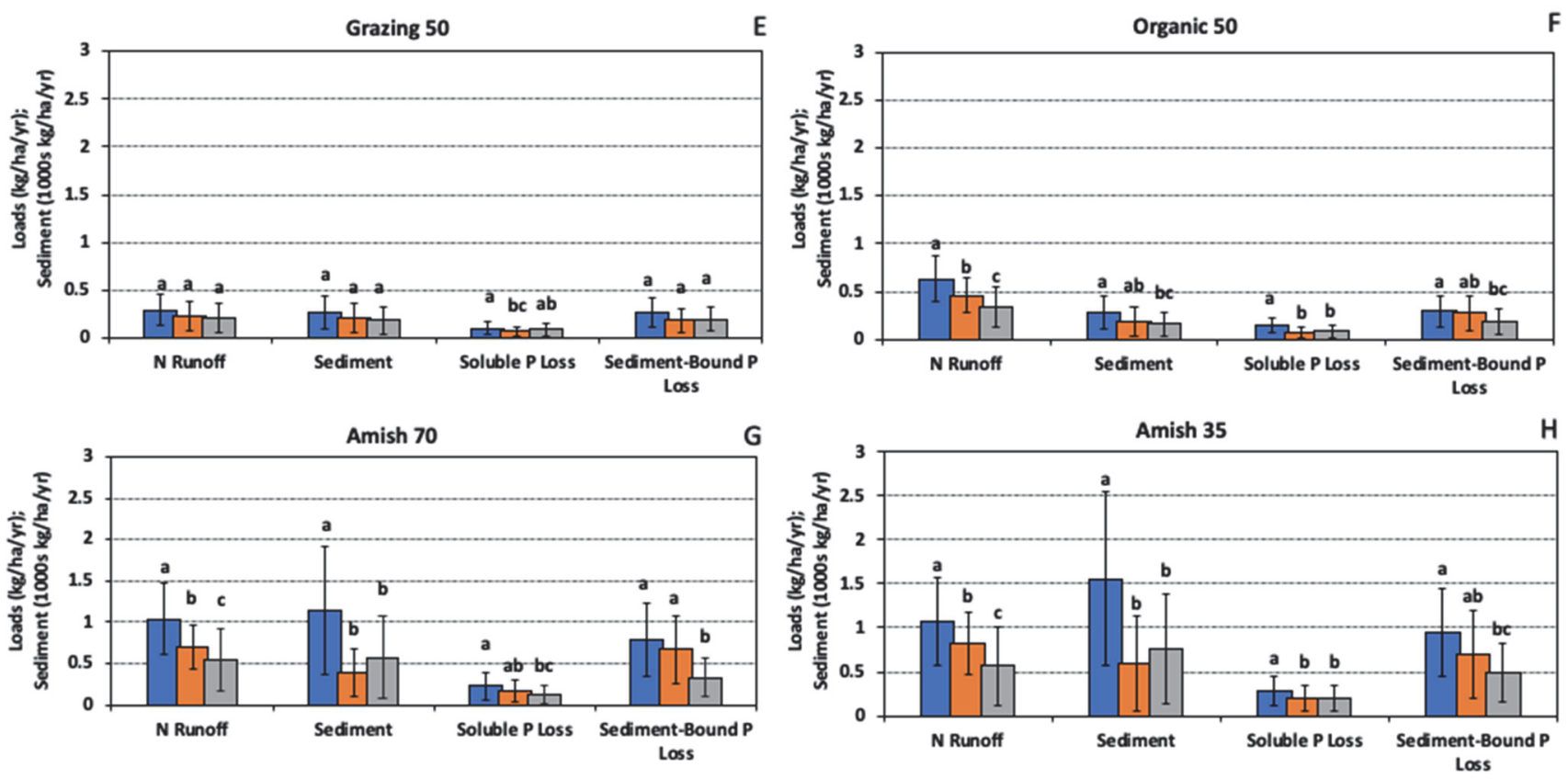

Figure 3. Average overland losses, simulated over 25 years, from (a) confined 150-cow, (b) confined 50-cow, (c) semi-confined 100-cow, (d) semiconfined 50-cow, (e) grazing 50-cow, (f) organic 50-cow, (g) Amish 70-cow, and (h) Amish 35-cow dairy operations. Error bars represent standard deviations. Different lowercase letters indicate significant difference at $\mathrm{p}<0.05$.

effective at achieving significant reductions as was observed for the rest of the farm operations. Erosion reductions ranged from $23 \%$ to $41 \%$ for the grazing and organic operations and from $30 \%$ to $66 \%$ among all farm operations.

Interseeded CC (scenario 3) provided similar benefits to the soil as post-harvest $\mathrm{CC}$, adding ground cover to what would otherwise be barren soil after corn-silage production, but achieved statistically greater benefits for the confined and semi-confined operations because the interseeded grass was planted on corn-grain land as well corn-silage land. For the two Amish farm types, reductions in erosion from the baseline were significant for both post-harvest $\mathrm{CC}$ and interseeded CC. Because these farms were simulated as using moldboard plowing in the spring, before corn planting, and providing additional ground cover during the year, erosion was reduced by $50 \%(\mathrm{p}<0.05)$. The grazing 50 -cow operation did not show a significant reduction in erosion. Because the majority of land on this farm was perennial pasture, erosion rates were low. Therefore, potential for improvement was low.

\section{Soluble P in Surface RunOFF}

In the simulation results for scenario 1 , farms with more land in crop rotation and less in perennial grassland saw greater nutrient and sediment losses. Soluble P loss via runoff was impacted by the use of cover crops and interseeding, 
with the driving factor being runoff. Overall, reductions of soluble $\mathrm{P}$ loss varied by farm type, with average reductions of $11 \%$ for cover cropping and $38 \%$ for interseeding. Other than correlation with surface runoff amounts, little pattern was associated with the changes in soluble P loss across the farm types.

\section{Sediment-Bound P In Surface RunofF}

Scenario 1 losses for sediment-bound $\mathrm{P}$ varied again by farm type, with greater losses from farms with more land in crop rotation and less in perennial grassland. The use of cover crops and interseeding resulted in average reductions in sediment-bound $\mathrm{P}$ loss of $23 \%$ and $45 \%$, respectively. Because sediment-bound $\mathrm{P}$ is directly associated with erosion loss, the greater reductions in sediment-bound $\mathrm{P}$ loss from interseeded grass (compared to the use of a cover crop) aligned with the greater reductions in erosion from the interseeded grass (fig. 3). This is due to the greater ability of interseeded grass to reduce sediment loss earlier in the growing season and because it was used on the entire corn crop.

\section{N LosS IN SURFACE RUNOFF}

$\mathrm{N}$ runoff (fig. 3), a large concern for the health of the Chesapeake Bay, was reduced with the use of cover crops and interseeding for the majority of the scenarios relative to the baseline. The use of cover crops provided $\mathrm{N}$ runoff reductions for seven of the eight operations, with semi-confined 50-cow being the exception. However, the reduction was small (average of 18\%) and found to be insignificant over all farm types. Greater reductions (24\% to $33 \%)$ were found on the organic and Amish farms, where more tillage was used $(\mathrm{p}<0.05)$. The use of interseeding provided greater reductions in $\mathrm{N}$ runoff ( $\mathrm{p}<0.05$ ), averaging $49 \%$ across the eight farms (ranging from $29 \%$ to $63 \%$ ). The grazing 50 -cow operation did not show a significant reduction in $\mathrm{N}$ runoff due to the small amount of $\mathrm{N}$ runoff from perennial grassland and the minimal use of corn on the farm. Because the majority of a grazing farm operation is pasture year-round, the farm is not susceptible to high nutrient and sediment losses, as compared to farms with confined operations using greater amounts of corn land for feed production. This is also illustrated by the two Amish farm, where nutrient losses per unit area were less for the larger farm, which contained relatively more perennial grassland.

\section{FARM-LEVEL ECONOMIC IMPACT}

The net economic return was compared across scenarios to determine the economic impact that cover cropping or interseeding might impose on each farm type (table 3 ). The goal of this analysis was to determine and compare the changes in total farm production costs with the use of a cover crop or interseeded grass.

Despite the additional costs associated with seeding and labor, the financial impact for adoption of cover cropping in most farm types appeared to be relatively minor. Annual production costs increased by up to $\$ 24 \mathrm{ha}^{-1}$ with cover cropping and by up to $\$ 63 \mathrm{ha}^{-1}$ for interseeding, with increases of less than $\$ 12 \mathrm{ha}^{-1}$ for most farms (table 3). Corn yields remained consistent across all farm types and scenarios (no statistically significant change) and therefore were not compensating or increasing the additional costs associated with cover crops or interseeding.

On average across the eight farms, adopting a cover crop increased production costs by $0.01 \%$ from the baseline. The semi-confined 100-cow, organic 50-cow, and Amish 35-cow operations experienced a slight decrease in production costs with the use of cover crops. The grazing 50-cow operation experienced the largest increase in production costs from adoption of cover crops $(0.9 \%)$, while the semi-confined 100 -cow operation experienced the largest decrease in production costs $(1.6 \%)$. Interseeding showed a slightly different trend, where seven of the eight farms experienced an increase in production costs, with an average increase of $0.4 \%$. The organic 50-cow operation was the only operation to experience a decrease in costs from interseeding $(0.4 \%)$. The confined 150-cow operation experienced the largest increase in costs of $1.6 \%$ from interseeding.

The reason for only minor increases or a decrease in production costs can be attributed to the conservation of $\mathrm{N}$ on the farm fields. The rye cover crop and interseeded grass took up much of the remaining $\mathrm{N}$ in the fall and held the $\mathrm{N}$ through the winter until it was killed just prior to corn planting in the spring. This rye or grass residue left on the field acted as a supplemental fertilizer as it decomposed, slowly releasing $\mathrm{N}$ back into the soil where it could be used by the newly planted corn, thus enabling producers to reduce fertilizer needs.

\section{Producer RECOMMENDATIONS}

Due to the reductions achieved for $\mathrm{N}$ runoff (up to $63 \%$ ), sediment loss $(30 \%$ to $66 \%)$, and sediment-bound P (7\% to $58 \%$ ), it is recommended that all dairy farms in the study area, regardless of size or type (e.g., organic, semi-confined, confined, or Amish) adopt a cover cropping practice, with post-harvest cover cropping or interseeded cover cropping both providing water quality benefits with relatively minor $(<2 \%)$ changes in annual production costs. Producers are

Table 3. Annual farm-scale production costs and change from baseline (scenario 1) of cover cropping (scenario 2) and interseeding (scenario 3) for each farm type simulated.

\begin{tabular}{|c|c|c|c|c|c|}
\hline \multirow[b]{2}{*}{ Farm Type } & \multicolumn{3}{|c|}{ Annual Production Cost $\left(\mathrm{USD} \mathrm{ha}^{-1}\right)$} & \multicolumn{2}{|c|}{ Percentage Change from Baseline (\%) } \\
\hline & Baseline & Cover Crop & Interseeding & Cover Crop & Interseeding \\
\hline Confined 150-cow & 3,722 & 3,746 & 3,785 & 0.63 & 1.69 \\
\hline Confined 50-cow & 3,283 & 3,293 & 3,307 & 0.31 & 0.75 \\
\hline Semi-confined 100 -cow & 4,842 & 4,763 & 4,855 & -1.63 & 0.27 \\
\hline Semi-confined 50-cow & 5,269 & 5,273 & 5,276 & 0.08 & 0.13 \\
\hline Grazing 50-cow & 3,184 & 3,212 & 3,195 & 0.86 & 0.33 \\
\hline Organic 50-cow & 4,945 & 4,942 & 4,926 & -0.06 & -0.38 \\
\hline Amish 70-cow & 4,039 & 4,041 & 4,043 & 0.05 & 0.10 \\
\hline Amish 35-cow & 5,737 & 5,721 & 5,742 & -0.28 & 0.10 \\
\hline
\end{tabular}


believed to be relatively open to conservation practices that focus on erosion control, as retaining their topsoil is crucial to the productivity and longevity of their farm (Kalcic et al., 2015). Additionally, the interest in and adoption of cover crops in the U.S. continues to expand (Hamilton et al., 2017). Therefore, the results of this study are likely to appeal to farmers wanting to implement practices that protect water quality while needing to understand the economic implications.

Primary limitations for a producer looking to adopt cover crops or interseeding is having access to the necessary equipment and capital required for establishing a cover crop and being able to invest the time necessary for establishing the added crop, which tends to be weather-dependent (RoeschMcNally et al., 2017). With that said, the results from this study should encourage the use of a cover crop practice because the long-term tradeoffs, such as decreased fertilizer needs, increased water-holding capacity, and improved soil fertility, often outweigh the initial barriers to entry.

\section{Policy ReCommendations}

Providing producers with the opportunity to earn water quality trading (WQT) credits for sediment and $\mathrm{P}$ reductions would further incentivize producers to adopt cover cropping BMPs. WQT provides a way for producers to recoup capital from BMP investments. However, even when applied to nonpoint-source issues, WQT programs have their own limitations and often lack flexibility that would encourage producer participation (Kalcic et al., 2015). For example, most current WQT programs are geared toward $\mathrm{N}$ reductions, with minimal compensation available for producers who are primarily reducing sediment and $\mathrm{P}$ losses. Thus, the lack of change in $\mathrm{N}$ runoff among scenarios in this study would likely not incentivize producers to adopt BMPs under current WQT programs.

\section{CONCLUSION}

This study analyzed the use of cover crops and interseeding as a means of nutrient and sediment control for dairy farms in central Pennsylvania. By using a whole-farm model (i.e., IFSM) to simulate adoption of cover crops or interseeding on eight typical dairy farm types, varied reductions in the masses of $\mathrm{N}, \mathrm{P}$, and sediment lost across each farm were found due to differences in perennial crop use. In particular, farms with more area in row crops relative to perennial grassland benefited more from reduced runoff and erosion by including cover crops, particularly when interseeded. Farms that use full tillage systems for crop establishment, such as the Amish farms, also obtained greater reductions in erosion and nutrient runoff using cover crops and interseeding. Reductions in N, P, and sediment losses were achieved across all eight farms with the use of cover crops and interseeding, with little impact on the producer's annual production costs. Therefore, the results of this study encourage the use of cover cropping and interseeding for nutrient and soil conservation. These results also improve understanding of how transferrable the benefits achieved from adoption of a specific practice at one farm may be to other farms.
Additionally, the results provide insight into the potential to scale up the results from single farm types to watersheds based on how many farms of each type are in an area of interest.

\section{ACKNOWLEDGEMENTS}

This work was funded by the Agriculture and Food Research Initiative (AFRI) Water for Agriculture (Grant No. 2017-68007-26584, Project Accession No. 1013079) from the USDA National Institute of Food and Water. H. E. Preisendanz, J. E. Watson, and H. A. Elliott are supported, in part, by the USDA National Institute of Food and Agriculture Federal Appropriations under Multi-State Project PEN04574 and Accession No. 1004448. K. J. Brasier is supported in part by the USDA National Institute of Food and Agriculture Federal Appropriations under Multi-State Project NC1190 and Accession No. 1011579. H. E. Preisendanz and K. J. Brasier are also supported, in part, by the Pennsylvania State University Institutes of Energy and the Environment. The authors wish to acknowledge the contributions of Weston Eaton, Virginia Ishler, John Tyson, and Walt Whitmer, whose collaborative efforts on the "Water $4 \mathrm{Ag}$ Project" made this research possible and relevant to key stakeholders. The findings and conclusions of this research do not necessarily reflect the views of the funding agency or Pennsylvania State University. The USDA-ARS and Pennsylvania State University are equal opportunity, affirmative action employers, committed to providing employment opportunities to all qualified applicants without regard to race, color, religion, age, sex, sexual orientation, gender identity, national origin, disability, or protected veteran status.

\section{REFERENCES}

Arguez, A., Durre, I., Applequist, S., Squires, M., Vose, R., Yin, X., \& Bilotta, R. (2010). NOAA's U.S. climate normals (19812010). Lewistown, PA: NOAA National Centers for Environmental Information.

Bowman, G., Cramer, C., \& Shirley, C. (2007). Managing cover crops profitably (3rd Ed.). College Park, MD: Sustainable Agriculture Research and Education (SARE). Retrieved from https://www.sare.org/resources/managing-cover-cropsprofitably-3rd-edition/

Chesapeake Bay Foundation. (2020). 2020 State of the blueprint. Annapolis, MD: Chesapeake Bay Foundation. Retrieved from https://www.cbf.org/how-we-save-the-bay/chesapeake-cleanwater-blueprint/2020-state-of-the-blueprint/

Clark, A. (2015). Cover crops for sustainable crop rotations. College Park, MD: Sustainable Agriculture Research and Education (SARE). Retrieved from https://www.sare.org/resources/cover-crops/

Curran, W. S., Hoover, R. J., Mirsky, S. B., Roth, G. W., Ryan, M. R., Ackroyd, V. J., ... Pelzer, C. (2018). Evaluation of cover crops drill interseeded into corn across the Mid-Atlantic region. Agron. J., 110(2), 435-443. https://doi.org/10.2134/agronj2017.07.0395

Fageria, N. K., Baligar, V. C., \& Bailey, B. A. (2005). Role of cover crops in improving soil and row crop productivity. Commun. Soil Sci. Plant Anal., 36(19-20), 2733-2757. https://doi.org/10.1080/00103620500303939

Fernández-Raga, M., Palencia, C., Keesstra, S., Jordán, A., Fraile, R., Angulo-Martínez, M., \& Cerdà, A. (2017). Splash erosion: A 
review with unanswered questions. Earth-Sci. Rev., 171, 463477. https://doi.org/10.1016/j.earscirev.2017.06.009

Hamilton, A. V., Mortensen, D. A., \& Allen, M. K. (2017). The state of the cover crop nation and how to set realistic future goals for the popular conservation practice. J. Soil Water Cons. 72(5), 111A-115A. https://doi.org/10.2489/jswc.72.5.111A

Hively, W. D., Duiker, S., McCarty, G., \& Prabhakara, K. (2015). Remote sensing to monitor cover crop adoption in southeastern Pennsylvania. J. Soil Water Cons., 70(6), 340-352. https://doi.org/10.2489/jswc.70.6.340

Holly, M. A., Gunn, K. M., Rotz, C. A., \& Kleinman, P. J. (2019). Management characteristics of Pennsylvania dairy farms. Appl. Animal Sci., 35(3), 325-338. https://doi.org/10.15232/aas.201801833

Jones, C. A., \& Kiniry, J. R. (Eds.). (1986). CERES-Maize: A simulation model of maize growth and development. College Station, TX: Texas A\&M University Press.

Jones, C. A., Cole, C. V., Sharpley, A. N., \& Williams, J. R. (1984). A simplified soil and plant phosphorus model: I. Documentation. SSSA J., 48(4), 800-805. https://doi.org/10.2136/sssaj1984.03615995004800040020x

Kalcic, M. M., Frankenberger, J., Chaubey, I., Prokopy, L., \& Bowling, L. (2015). Adaptive targeting: Engaging farmers to improve targeting and adoption of agricultural conservation practices. JAWRA, 51(4), 973-991. https://doi.org/10.1111/17521688.12336

Liu, Y., Engel, B. A., Flanagan, D. C., Gitau, M. W., McMillan, S. K., \& Chaubey, I. (2017). A review on effectiveness of best management practices in improving hydrology and water quality: Needs and opportunities. Sci. Total Environ., 601-602, 580-593. https://doi.org/10.1016/j.scitotenv.2017.05.212

McLean, A. (2011). Modeling best management practices on representative farms in southeastern Pennsylvania using the Integrated Farm System Model. MS thesis. University Park, PA: Pennsylvania State University. Retrieved from https://etda.libraries.psu.edu/catalog/14093

Moore, E. B., Wiedenhoeft, M. H., Kaspar, T. C., \& Cambardella, C. A. (2014). Rye cover crop effects on soil quality in no-till corn silage-soybean cropping systems. SSSAJ, 78(3), 968-976. https://doi.org/10.2136/sssaj2013.09.0401

Pelton, T., \& Goldsborough, B. (2008). Bad water and the decline of blue crabs in the Chesapeake Bay. Annapolis, MD:

Chesapeake Bay Foundation. Retrieved from https://www.cbf.org/document-library/cbfreports/CBF_BadWatersReport6d49.pdf

PADEP. (2017). Kishacoquillas Creek watershed alternative restoration plan: Mifflin County, Pennsylvania. Harrisburg, PA: Pennsylvania Department of Environmental Protection. Retrieved from http://www.dep.state.pa.us/dep/deputate/watermgt/wqp/wqstand ards/tmdl/Kishacoquillas_Creek_ARP.pdf

PADEP. (2019). Pennsylvania Phase 3 Chesapeake Bay Watershed Implementation Plan. Harrisburg, PA: Pennsylvania Department of Environmental Protection

Reese, S. O., \& Risser., D. W. (2010). Summary of groundwaterrecharge estimates for Pennsylvania. Water Resource Report 70. Harrisburg, PA: Pennsylvania Geological Survey. Retrieved from

http://wren.palwv.org/library/documents/PAGroundwaterReport $-2010 . p d f$

Reuter, J. (2005). Erosion rates and patterns inferred from cosmogenic 10BE in the Susquehanna River basin. MS thesis. Burlington, VT: University of Vermont. Retrieved from $\mathrm{http} / / /$ www.uvm.edu/ cosmolab/people/reuterj/reuterms_thesis. pdf
Roesch-McNally, G. E., Basche, A. D., Arbuckle, J. G., Tyndall, J. C., Miguez, F. E., Bowman, T., \& Clay, R. (2017). The trouble with cover crops: Farmers' experiences with overcoming barriers to adoption. Renew. Agric. Food Syst., 33(4), 322-333. https://doi.org/10.1017/S1742170517000096

Roth, G. W., \& Curran., W. S. (2017). Cover crop interseeder: Impacts on corn yield. University Park, PA: Pennsylvania State University Extension. Retrieved from

https://extension.psu.edu/cover-crop-interseeder-impacts-oncorn-yield.

Roth, G. W., Curran, W. S., Dillon, C., Houser, C., \& Harkcom, W. S. (2015). Cover crop interseeder and applicator. University Park, PA: Pennsylvania State University Extension. Retrieved from http://extension.psu.edu/plants/crops/soilmanagement/cover-crops/interseeder-applicator

Rotz, C. A., Corson, M. S., Chianese, D. S., Montes, F., Hafner, S. D., Bonifacio, H. F., \& Coiner, C. U. (2018). Integrated Farm System Model: Reference manual, Ver. 4.4. Washington, DC: USDA Agricultural Research Service. Retrieved from https://www.ars.usda.gov/ARSUserFiles/80700500/Reference\% 20Manual.pdf

Sanford, W. E., \& Selnick, D. L. (2013). Estimation of evapotranspiration across the conterminous United States using a regression with climate and land-cover data. JAWRA, 49(1), 217-230. https://doi.org/10.1111/jawr.12010

Schnitkey, G., Swanson, K., Coppess, J., \& Armstrong, S. (2018). Managing the economics of planting cereal rye as a cover crop. Farmdoc daily(8), 151.

Schubel, J. R., \& Pritchard, D. W. (1986). Responses of upper Chesapeake Bay to variations in discharge of the Susquehanna River. Estuaries, 9(4), 236-249. https://doi.org/10.2307/1352096

Sedorovich, D. M., Rotz, C. A., Vadas, P. A., \& Harmel, R. D. (2007). Simulating management effects on phosphorus loss from farming systems. Trans. ASABE, 50(4), 1443-1453. https://doi.org/10.13031/2013.23617

Selman, M., Greenhalgh, S., Diaz, R., \& Sugg, Z. (2008). Eutrophication and hypoxia in coastal areas: A global assessment of the state of knowledge. WRI Policy Note. Washington, DC: World Resources Institute. Retrieved from https://files.wri.org/s3fspublic/pdf/eutrophication_and_hypoxia_in_coastal_areas.pdf

Syvitski, J. P., Vorosmarty, C. J., Kettner, A. J., \& Green, P. (2005). Impact of humans on the flux of terrestrial sediment to the global coastal ocean. Science, 308(5720), 376-380. https://doi.org/10.1126/science.1109454

Thapa, R., Mirsky, S. B., \& Tully, K. L. (2018). Cover crops reduce nitrate leaching in agroecosystems: A global meta-analysis. $J$. Environ. Qual., 47(6), 1400-1411. https://doi.org/10.2134/jeq2018.03.0107

USDA-NASS. (2017). Census of agriculture. Washington, DC: USDA National Agricultural Statistics Service. Retrieved from https://www.nass.usda.gov/Publications/AgCensus/2017/index.p hp\#full_report

USDA-NRCS. (2003). Updated T and K factors. Washington, DC: USDA Natural Resources Conservation Service. Retrieved from https://www.nrcs.usda.gov/Internet/FSE_DOCUMENTS/nrcs14 2p2_019867.pdf

USDA-NRCS. (2004). Chapter 9: Hydrologic soil-cover complexes. In National engineering handbook: Part 630. Hydrology. Washington, DC: USDA Natural Resources Conservation Service. Retrieved from https://directives.sc.egov.usda.gov/OpenNonWebContent.aspx?c ontent $=17758$.wba

USDA-NRCS. (2020). Web soil survey. Washington, DC: USDA Natural Resources Conservation Service. Retrieved from https://websoilsurvey.sc.egov.usda.gov 
USEPA. (2010). Chapter 2. Agriculture. In Guidance for federal land management in the Chesapeake Bay watershed. EPA841R-10-002. Washington, DC: U.S. Environmental Protection Agency. Retrieved from

https://www.epa.gov/sites/production/files/2015-

10/documents/chesbay_chap02.pdf
Williams, J. R. (1995). Chapter 25: The EPIC model. In V. P. Singh (Ed.), Computer models of watershed hydrology (pp. 909-1000). Highlands Ranch, CO: Water Resources Publications.

Yu, Y., Loiskandl, W., Kaul, H.-P., Himmelbauer, M., Wei, W., Chen, L., \& Bodner, G. (2016). Estimation of runoff mitigation by morphologically different cover crop root systems. $J$. Hydrol., 538, 667-676.

https://doi.org/10.1016/j.jhydrol.2016.04.060 